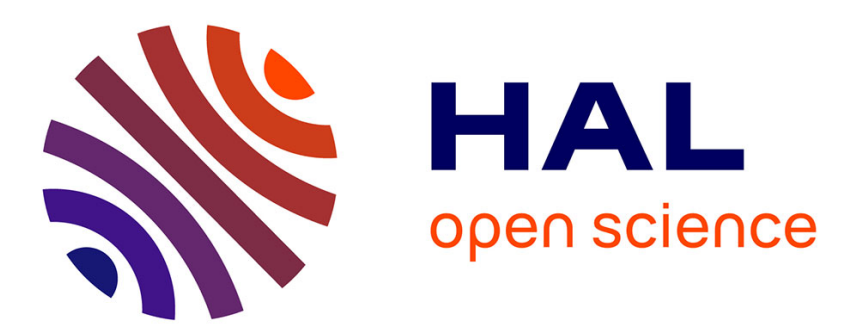

\title{
Use of diatom life-forms and ecological guilds to assess pesticide contamination in rivers: lotic mesocosm approaches
}

\author{
Frédéric Rimet, Agnes Bouchez
}

\section{- To cite this version:}

Frédéric Rimet, Agnes Bouchez. Use of diatom life-forms and ecological guilds to assess pesticide contamination in rivers: lotic mesocosm approaches. 4th CE-Diatom Meeting, Mar 2010, Reichenau, Germany. 2 p. hal-02817780

\section{HAL Id: hal-02817780 \\ https://hal.inrae.fr/hal-02817780}

Submitted on 6 Jun 2020

HAL is a multi-disciplinary open access archive for the deposit and dissemination of scientific research documents, whether they are published or not. The documents may come from teaching and research institutions in France or abroad, or from public or private research centers.
L'archive ouverte pluridisciplinaire HAL, est destinée au dépôt et à la diffusion de documents scientifiques de niveau recherche, publiés ou non, émanant des établissements d'enseignement et de recherche français ou étrangers, des laboratoires publics ou privés. 


\title{
Use of diatom life-forms and ecological guilds to assess pesticide contamination in rivers: lotic mesocosm approaches
}

\author{
RIMET Frédéric and BOUCHEZ Agnès \\ INRA, UMR Carrtel, 75 av. de Corzent, BP 511, F-74203 Thonon les Bains cedex, France \\ rimet@thonon.inra.fr
}

\begin{abstract}
The persistence of pesticides in the environment and their effects are a cause of concern to more and more people, and so in 2009 the French government announced plans to reduce pesticide use in agriculture over the next 10 years. Water managers are to monitor the beneficial impact of this reduction on aquatic environments. It has been suggested that diatoms may be good indicators of pesticides, and more particularly of herbicides, in water. Diatoms have been routinely used to assess organic and nutrient pollution for more than 10 years. The general approach is to develop a diatom-based tool to assess pesticide contamination. Diatom indices are usually based on specific pollution sensitivity. Other metrics, such as life-forms, ecological guilds, or cell size offer other advantages. For instance, the relationships between trends in these parameters and environmental gradients are more robust, and make it easier to establish ecological hypotheses. We have therefore opted for this approach.
\end{abstract}

To develop such a tool, outdoor, lotic mesocosm experiments lasting about 2 months were conducted from 2006 to 2008. Herbicides (diuron) and fungicides (azoxystrobin, tebuconazole) were tested at environmental concentrations (around $1.5 \mu \mathrm{g} . \mathrm{l}-1$ for chronic pollution and around $20 \mu \mathrm{g} . \mathrm{l}-1$ for short-term or acute pollution). Diatom communities in artificial channels were analyzed by light microscopy using standard European methods. The various parameters structuring diatom communities were assessed, and colonization time appeared to be the most important. However, pesticide contamination was the second most important, and had a more significant impact on the composition of ecological guilds than on species composition. Some metrics did not display any significant trends (benthic/planktonic, colonial, pedunculate, pioneer), but others looked promising for use in pesticide contamination assessment: the abundances of motile-guild, low-profile guild and mucous tubule diatoms all increased in contaminated channels, whereas high-profile diatoms showed the opposite trend. Some possible explanations, such as a protective effect of the exopolysaccharide matrix, can be advanced: diatoms living inside a mucous tubule may be shielded from dissolved pesticides, as are motile diatoms, which have a micro-habitat preference for thick matrices which also allows them to withstand higher levels of water contamination. In the same way, high-profile guild diatoms are exposed to dissolved pesticides to a greater extent, and this could explain their lower abundance in contaminated channels. 